\title{
Perioperative respiratory distress in a child due to plastic bronchitis triggered by allergic reaction to sevoflurane
}

\author{
Yongsheng Qiu, ${ }^{1}$ Ran Zhang (i) ${ }^{2}$
}

${ }^{1}$ Anesthesiology, Children's Hospital to Zhengzhou University, Zhengzhou, Henan, China

${ }^{2}$ Anesthesiology, Brown University Warren Alpert Medical School, Providence, Rhode Island, USA

Correspondence to Dr Ran Zhang;

ran_zhang@brown.edu

Accepted 2 September 2020
Check for updates

(c) BMJ Publishing Group Limited 2020. No commercial re-use. See rights and permissions. Published by BMJ.

To cite: Qiu Y, Zhang R. BMJ Case Rep 2020;13:e236378. doi:10.1136/bcr-2020236378

\section{DESCRIPTION}

This was a 3 -year-old boy, of weight $15 \mathrm{~kg}$, with no significant medical history receiving tonsillectomy due to obstructive sleep apnoea. General anaesthesia was induced with midazolam, propofol, remifentanil and cisatracurium, and airway was secured with $4.0 \mathrm{~mm}$ oral endotracheal tube. After sevoflurane was introduced to maintain anaesthesia, the peak airway pressure suddenly rose to $45 \mathrm{cmH}_{2} \mathrm{O}$ and wheezing breath sounds were auscultated bilaterally. Such symptoms resolved with bronchodilation and antihistamine treatment, and he was extubated after the surgery was cancelled. Overnight he suddenly developed cough and difficulty in breathing, then he coughed out a soft translucent viscous cast shaping as tree branches (figure 1). The chest radiograph showed non-specific atelectasis. The pathological result of the excreted airway cast demonstrated necrotic detachment epithelium and inflammatory exudate, where neutrophils were the main inflammatory cells (figure 2). His allergenspecific IgE test was positive for latex and inhalation anaesthetics, and in vitro basophil activation assay was positive for sevoflurane. The patient was discharged home in post-anaesthesia day 7 with no other complications. There was no evidence of recurrence at follow-up of 3 months.

Plastic bronchitis $(\mathrm{PB})$ is a rare but serious respiratory disease which is characterised by the formation of a plastic foreign matter that leads to partial or extensive obstruction in the respiratory tract. Although PB was first reported over a century ago, its causes still remain unclear. ${ }^{1}$ The patients present with difficulty in breathing or even respiratory failure. ${ }^{2}$ The overall incidence of $\mathrm{PB}$ is approximately 6.8/100 000, with increased risk among patients with congenital heart disease, pneumonia or influenza and asthma. ${ }^{3}$ Based on histology $\mathrm{PB}$ has been classified into: type I inflammatory cell type, characterised by numerous inflammatory cells (mainly of eosinophils and neutrophils) and cellulose; type II non-inflammatory cell type, characterised by non-cellular substance (mainly of mucin and little cellulose), which is more common after surgery of congenital heart disease with associated abnormal lymphatic drainage. ${ }^{4}$ Children with reactive airway disease are more prone to the development of type I cast, and the cause is related to inflammatory reaction and consequent neutrophils and eosinophils infiltration. ${ }^{3}$ This patient developed airway inflammation due to allergic reaction to the volatile agent sevoflurane, subsequently

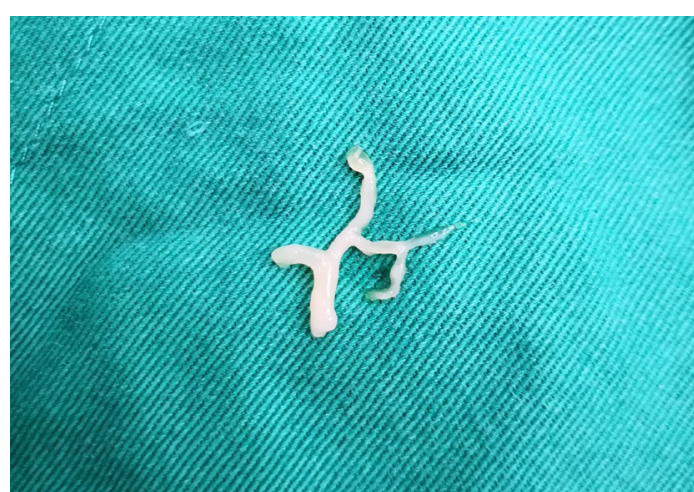

Figure 1 Bronchial cast removed from the patient, showing the shape of bronchial tree.

confirmed by immunology testing. The diagnosis of $\mathrm{PB}$ is confirmed by presentation of bronchial cast which is obtained by the patient's spontaneous coughing, manual suction via the tracheal intubation or by bronchoscopy. ${ }^{5}$ The expectorated cast by presented patient was composed mainly of inflammatory cells, supporting the diagnosis of type I PB. The treatment of $\mathrm{PB}$ focuses on prompt cast removal by bronchoscopy and chronic prevention of cast recurrence. Rigid bronchoscopy and flexible bronchoscopic cryoextraction provide improved airway clearance. ${ }^{67}$ In addition, mucolytics (tissuetype plasminogen activator, heparin, urokinase) and fibrinolytics (acetylcysteine, dornase) have been used by either inhalation or directly instilled via bronchoscope to facilitate cast disruption. ${ }^{2}$

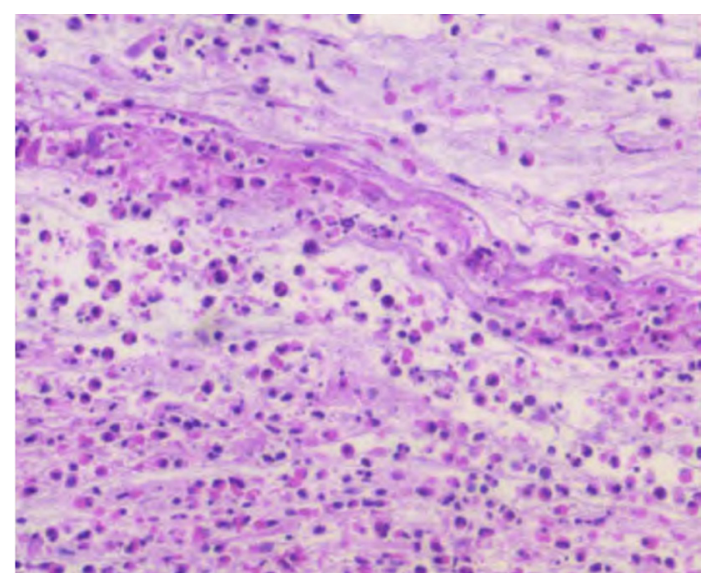

Figure 2 Histology of the excreted airway cast, demonstrating necrotic detachment epithelium and inflammatory exudate. 
Bronchodilator, inhaled and systemic corticosteroids and azithromycin are commonly used medical therapeutic adjuncts. ${ }^{8}$ Percutaneous lymphatic embolisation has recently been reported to be effective intervention for PB after surgically corrected congenital heart disease with acquired lymphangiectasia. ${ }^{9}$

\section{Learning points}

- The incidence of childhood plastic bronchitis (PB) is rare, yet the onset is usually obscure followed by rapid development.

- The clinical manifestations and imaging findings of PB are non-specific, therefore its diagnosis is difficult and mainly based on bronchoscopy and histopathological examination.

- Inhaled anaesthetics should not be neglected as a potential trigger when perioperative allergic reactions happen among highly sensitive children.

Contributors Both YQ and RZ wrote and edited the manuscript.

Funding The authors have not declared a specific grant for this research from any funding agency in the public, commercial or not-for-profit sectors.

Competing interests None declared.

Patient consent for publication Parental/guardian consent obtained.

Provenance and peer review Not commissioned; externally peer reviewed.

\section{ORCID iD}

Ran Zhang http://orcid.org/0000-0002-9394-0418

\section{REFERENCES}

1 Beitmann M. Report of a case of fibrinous bronchitis, with a review of all cases in the literature. Am J Med Sci 1902;123:304-29.

2 Colaneri M, Quarti A, Pozzi M, et al. Management of plastic bronchitis with nebulized tissue plasminogen activator: another brick in the wall. Ital J Pediatr 2014;40:18.

3 Kunder R, Kunder C, Sun HY, et al. Pediatric plastic bronchitis: case report and retrospective comparative analysis of epidemiology and pathology. Case Rep Pulmonol 2013;2013:1-8

4 Seear $\mathrm{M}$, Hui H, Magee F, et al. Bronchial casts in children: a proposed classification based on nine cases and a review of the literature. Am J Respir Crit Care Med 1997:155:364-70.

5 Preciado D, Verghese S, Choi S. Aggressive bronchoscopic management of plastic bronchitis. Int J Pediatr Otorhinolaryngol 2010;74:820-2

6 Soyer T, Yalcin Sule, Emiralioğlu N, et al. Use of serial rigid bronchoscopy in the treatment of plastic bronchitis in children. J Pediatr Surg 2016;51:1640-3.

7 Sriratanaviriyakul N, Lam F, Morrissey BM, et al. Safety and clinical utility of flexible bronchoscopic cryoextraction in patients with Non-neoplasm tracheobronchial obstruction: a retrospective chart review. J Bronchology Interv Pulmonol 2015:22:288-93.

8 Schultz KD, Oermann CM. Treatment of cast bronchitis with low-dose oral azithromycin Pediatr Pulmonol 2003;35:139-43.

9 Dori Y, Keller MS, Rome JJ, et al. Percutaneous lymphatic embolization of abnormal pulmonary lymphatic flow as treatment of plastic bronchitis in patients with congenital heart disease. Circulation 2016:133:1160-70.

Copyright 2020 BMJ Publishing Group. All rights reserved. For permission to reuse any of this content visit https://www.bmj.com/company/products-services/rights-and-licensing/permissions/

BMJ Case Report Fellows may re-use this article for personal use and teaching without any further permission.

Become a Fellow of BMJ Case Reports today and you can:

- Submit as many cases as you like

- Enjoy fast sympathetic peer review and rapid publication of accepted articles

- Access all the published articles

- Re-use any of the published material for personal use and teaching without further permission

\section{Customer Service}

If you have any further queries about your subscription, please contact our customer services team on +44 (0) 2071111105 or via email at support@bmj.com.

Visit casereports.bmj.com for more articles like this and to become a Fellow 